\title{
Mechanical properties and microstructure of high performance concrete containing stabilized nano-silica
}

\author{
Gustavo Braz de Abreu ${ }^{1}$, Suéllen Mota Marques Costa ${ }^{1}$, \\ Adriana Guerra Gumieri ${ }^{1}$, José Márcio Fonseca Calixto ${ }^{1}$, \\ Fabrício Carlos França $^{2}$, Cláudio Silva ${ }^{3}$, Alberto Delgado Quinõnes ${ }^{4}$
}

\author{
${ }^{1}$ Escola de Engenharia, Universidade Federal de Minas Gerais, Av. Antônio Carlos, 6627, Pampulha, 31270-901 Belo \\ Horizonte, MG, Brasil \\ e-mails:gustavobrazdeabreu@gmail.com;suellenmc@hotmail.com; adriana@demc.ufmg.br; calixto@dees.ufmg.br \\ ${ }^{2}$ Holcim,Fábrica de Cimento Pedro Leopoldo, Fazenda Vargem Alegre, S/N, Bairro Vargem Alegre, 33600-000 Pedro \\ Leopoldo, MG, Brasil \\ e-mail: fabriciocarlos.franca@llafargeholcim.com \\ ${ }^{3}$ Wanmix, Rua Paulo Ferreira Costa, 440, Bairro Vista Alegre, 33400-000 Lagoa Santa, MG, Brasil \\ e-mail: claudiosilva136@gmail.com \\ ${ }^{4}$ Tecnosil/Silicon, Rua Américo Simões,119 A, Bairro São Roque da Chave, 13295-000 Itupeva,SP, Brasil \\ e-mail: alberto@tecnosilbr.com.br
}

\begin{abstract}
Nanotechnology can significantly improve the mechanical strength and durability of concrete. At the nanoscale, good dispersion of constituent materials is an essential factor for the improvement of concrete properties. In this scenario, the objective of this research was to evaluate the mechanical properties of high performance concrete containing stabilized nano-silica. The incorporation of nano-silica to the polycarboxylate chemical admixture allowed its application in concrete, since the nano-silica was evenly dispersed in the concrete mass. For this study, three different concretes were employed: a reference concrete, one containing stabilized nano-silica and another containing a mixture of silica fume and stabilized nanosilica. The evaluated concrete mechanical properties were the axial compressive strength and secant modulus of elasticity measured in three different ages. The results indicated a substantial increase in concrete compressive strength and modulus of elasticity with the addition of stabilized nano-silica combined with a reduction in cement content. The results also showed that use of stabilized nano-silica proved to be very advantageous, especially when mixed with silica fume. When they were combined, a synergy effect occurred in the concrete that was of chemical nature in addition to the physical effect of better concrete particle packaging. Analysis by scanning electron microscopy showed the improvement in microstructure of concretes with stabilized nano-silica, which contributed to gains in mechanical properties.
\end{abstract}

Keywords: Nano-silica, high performance concrete, compressive strength, secant modulus of elasticity, microstructure.

\section{INTRODUCTION}

High performance concrete is essentially a concrete having a low water/cement ratio to ensure longer service life and adequate mechanical strength specified by design. The strength of the hydrated cement paste used in this type of concrete can be improved by reducing its porosity, since a large number of large pores or voids, especially when concentrated in a certain location, reduces the mechanical strength and the durability of concrete. Grain size of materials used also influences the properties of concrete because the strength of a crystalline phase increases with decreasing grain size [1].

The use of nanotechnology can significantly improve the property of various types of materials, such as plastics, metals or carbon fibers, for example. The use of nanomaterials allows for increased contact and surface reactivity, promoting improvement in the properties of the materials. The application of nanomaterials in concrete production enables the improvement of its properties, since the mechanical strength and the service life of concrete structures are determined by its microstructure [2]. The proper use of nanomaterials can still decrease the dimensions and the weight of the concrete structures, and may generate a significant 
economy in the use of natural resources, especially with regard to the consumption of cement, and in some cases other components (steel, aggregates and water).

In the case of cementitious materials, nanotechnology can improve their properties such as cohesion, cracking due to water loss by drying or under endogenous conditions, mechanical strength, ductility [2,3], and corrosion of reinforcement [4]. Several studies on nanomaterials applied to cementitious materials can be found in the literature [5-13]. Overall, the research focused in the addition of nano-silica or carbon nanotubes to Portland cements, mortars and concretes. The analysis included the evaluation of the rheological properties, compressive and flexural strength, microstructure and durability.

At the nanoscale, good dispersion of materials is an essential factor for the improvement of concrete properties $[13,14]$. The mechanical properties of the nanocomposites are influenced by the level of dispersion of the particles in the matrix. The better performance of nano-sized materials in the cement paste is obtained by the uniform distribution of the same. When a matrix is made up of materials that exhibit largesized particles, the maximum dispersion of minor inclusions (nanoparticles) is reduced due to the formation of large contiguous volumes that are inaccessible to nano-inclusions [14]. When nanomaterials are used in the cement, the cement volume induces some sort of agglomeration of nano-particles. In practice, the cement particles can form lumps before and during the production of the paste. The size of lumps can reach hundreds of microns, causing also the agglutination of nanoparticles. The cement particle size is not the only factor influencing dispersion: the used percentage has also an effect. Normally, a good dispersion of nanoinclusions is more difficult to achieve in relation to larger materials. Concrete is composed of materials of various sizes and proportions that behave non-continuously; therefore, the inclusion of nanomaterials in this case is more complex [14]. In this way, materials with highly dispersing characteristics when incorporated into the concrete allow the improvement of its properties.

$\mathrm{SiO}_{2}$ nanoparticles were very effective in improving concrete workability, durability and mechanical strength [15]. The pozzolanic activity of nano-silica in the cement paste has proved to be more efficient than the silica fume due to its higher specific surface area [15-17]. The use of nano-silica was also efficient in concrete reinforced with polypropylene fibers [18]. When only polypropylene fibers were used in the concrete, their contribution was not very positive due to poor dispersion. However, when used with the nanosilica, the concrete gained more strength because the nanomaterial contributed to a porosity reduction at the transition zone between the fibers and the cement paste.

Supplementary cementitious materials are widely used in concrete. These materials can be cementing, fillers or pozzolanic. Their effects on the kinetic reactions are complex due to their interactions with the phases of the clinker. In the early stages, the filler effect is dominant which increases the rate of the clinker phase reactions due to nucleation [19]. The reactivity of pozzolans depends on the chemical composition, the vitreous degree and fineness of the material, although these are not the only factors that influence their reactivity [20]. Pozzolans were originally used in concretes and mortars due to their reaction with $\mathrm{Ca}(\mathrm{OH})_{2}$ released during cement hydration. $\mathrm{Ca}(\mathrm{OH})_{2}$ susceptible to chemical attack is then reduced, and in its place CSH gel and other products are formed increasing concrete durability [21]. Artificial pozzolans can also be used such as fly ash, silica fume, rice husk ash among other materials originated from industrial processes $[21,22]$.

The addition of micro and nano-size particles of pozzolanic materials influences the transformation of calcium hydroxide into hydrated calcium silicate according to Hemalatha et al. [23]. In XRD analyses carried out on cement pastes, calcium hydroxide peaks in pastes containing only cement have a higher intensity when compared to pastes made with cement and pozzolanic additions. The microstructure of the cement paste with nano-additions also appears denser in comparison to pastes produced with larger particle size pozollans [23].

The cements produced worldwide contain, on average, approximately $5 \%$ gypsum, $12 \%$ of supplementary cementitious materials (blast furnace slag, lime and pozzolan) and $83 \%$ of clinker [24]. Due to the increasing clinker replacement by supplementary cementitious materials, the clinker content in cement is being gradually decreased, and as a result, $\mathrm{CO}_{2}$ emissions during cement production. Nanomaterials used as cementitious materials may therefore contribute to the reduction of these emissions by reducing the cement content needed to achieve certain requirements in concrete.

Currently some mineral additions are grinded to achieve nano-scale particle sizes. Particle size reduction can improve the properties of cementitious materials such as the filler and pozzolanic effects. Water demand and workability of cement pastes containing nano-silica were evaluated by Quercia et al. [11]. With nano-silica rates above $1.5 \%$ with respect to cement content, the pastes showed quite hard consistency, as result of high cohesive forces between the particles due to their higher surface area. 
Senff et al. [12] investigated the rheological behavior of cement pastes containing silica fume, nanosilica and polycarboxylate based chemical admixture. The used nano-silica was in the form of a suspension. The results showed that the high reactivity of the nano-silica and silica fume due to their larger surface area led to an increase in the initial yield stress of the pastes when the plastic viscosity was kept constant.

Besides the pozzolanic activity of nano-silica, these particles can also act as nucleation sites due to their high specific surface area accelerating the hydration of the cement paste [23, 25-30]. Nano-silica reacts quickly with the calcium hydroxide released during cement hydration generating mineral compounds similar to $\mathrm{CSH}$ gel produced by cement.

Addition of colloidal silica sol with mono-dispersed nano-particles has shown a more significant accelerating effect on cement hydration than that of powered nano-silica [30]. As result of the accelerating effect on cement hydration, most of compressive strength gain of cement pastes containing nano-silica is attained within the first 7 days [13].

Only a few studies evaluate the modulus of elasticity of concrete produced with nanomaterials. The rheological properties as well as the mechanical properties and microstructure of self-consolidated concrete with the addition of nano-silica were investigated by Maghsoudi et al. [9].The results indicated that there was improvement of compressive and flexural strengths and modulus of elasticity of concrete with nano-silica.

With regard to the use of nano-silica and silica fume, test results of chloride penetration in concrete have shown that nano-silica is more efficient than the silica fume under the same conditions. However, when combined, better performance was achieved [10].

In this scenario, the objective of this research was to evaluate the mechanical properties and microstructure of high performance concrete containing stabilized nano-silica. For this study, three different concretes were employed: a reference concrete, one containing stabilized nano-silica and another containing a mixture of silica fume and stabilized nano-silica. The evaluated concrete mechanical properties were the axial compressive strength and modulus of elasticity measured in three different ages. Scanning electron microscopy was used in the microstructure analysis.

\section{MATERIALS AND EXPERIMENTAL PROCEDURES}

\subsection{Materials}

Brazilian type CP V ARI PLUS Portland cement [31] (ASTM Type III) was used since it does not have any supplementary cementitious materials (blast furnace slag, lime and pozzolan). The cement characteristics are shown in Table 1. Based on the chemical analysis of this cement, the potential composition, calculated according to Bogue [32-35], resulted on the following: $\mathrm{C}_{3} \mathrm{~S}=69.3 \%, \mathrm{C}_{2} \mathrm{~S}=11.6 \%, \mathrm{C}_{3} \mathrm{~A}=8.6 \%$ and $\mathrm{C}_{4} \mathrm{AF}=$ $10.4 \%$.

Quartz sand with a fineness modulus of 2.40 was used as fine aggregate. As coarse aggregate, gneiss was employed; it had a specific gravity equal to $2.680 \mathrm{~g} / \mathrm{cm}^{3}$. The coarse aggregate size distribution was composed of $80 \%$ and $20 \%$ of aggregates with maximum dimensions of 19 and $12.5 \mathrm{~mm}$, respectively.

Two different active silica based mineral additions were used: silica fume and stabilized nano-silica. Silica fume showed an amorphous $\mathrm{SiO}_{2}$ content greater than $85 \%$, a specific surface of $20,000 \mathrm{~m} / \mathrm{kg}$, and a specific gravity of $2.220 \mathrm{~g} / \mathrm{cm}^{3}$. Particle shape was spherical with a size between $200 \mathrm{~nm}$ and $1 \mu \mathrm{m}$. This silica fume was in aqueous suspension in a 50:50 ratio.

The employed nano-silica was evenly dispersed and stabilized in the polycarboxylate based chemical admixture. This fact allowed the nano-silica particles to be well distributed throughout the mass of concrete at the time of mixing and casting. The nano-silica typical size was between 3 and $200 \mathrm{~nm}$.

A multifunctional setting retardant plasticizer was used in all the concretes. It had a specific gravity equal to $1.23 \mathrm{~g} / \mathrm{cm}^{3}$. According to its specifications, it can be used in conjunction with superplasticizers admixtures.

The employed water was locally supplied and satisfied the requirements of Brazilian NBR 15900-1 standard [36]. 
ABREU, G.B.; COSTA, S.M.M.; GUMIERI, A.G.; CALIXTO, J.M.F.; FRANÇA, F.C.; SILVA, C.; QUINÕNES, A.D. revista Matéria,

Table 1: Brazilian type CP V ARI PLUS Portland cement characteristics (ABNT NBR 5733).

\begin{tabular}{|c|c|c|}
\hline \multicolumn{3}{|l|}{ CHEMICAL COMPOSITION } \\
\hline PROPERTIES & RESULTS & NBR 5733 SPECIFICATIONS \\
\hline Insoluble residue $(\%)$ & 0.73 & $\leq 1.0$ \\
\hline Loss on ignition $-1000^{\circ} \mathrm{C}(\%)$ & 3.63 & $\leq 4.5$ \\
\hline Loss on ignition $-500^{\circ} \mathrm{C}(\%)$ & 0.76 & - \\
\hline $\mathrm{SiO}_{2}(\%)$ & 19.37 & - \\
\hline $\mathrm{Al}_{2} \mathrm{O}_{3}(\%)$ & 4.73 & - \\
\hline $\mathrm{Fe}_{2} \mathrm{O}_{3}(\%)$ & 2.98 & - \\
\hline $\mathrm{CaO}(\%)$ & 63.58 & - \\
\hline $\mathrm{MgO}(\%)$ & 0.70 & $\leq 6.5$ \\
\hline $\mathrm{SO}_{3}(\%)$ & 2.98 & $\leq 4.5$ \\
\hline $\mathrm{CO}_{2}(\%)$ & 2.65 & $\leq 3.0$ \\
\hline $\mathrm{K}_{2} \mathrm{O}(\%)$ & 0.82 & - \\
\hline
\end{tabular}

PHYSICAL PROPERTIES

\begin{tabular}{l|l|l}
\hline Specific surface - Blaine $\left(\mathrm{m}^{2} / \mathrm{kg}\right)$ & 474.2 & $\geq 300$ \\
\hline Specific gravity $\left(\mathrm{g} / \mathrm{cm}^{3}\right)$ & 3.07 & - \\
\hline Fineness mesh $\# 400(\%)$ & 2.5 & - \\
\hline Initial setting $(\mathrm{min})$ & 131 & $\geq 60$ \\
\hline Final setting $(\mathrm{min})$ & 188 & $\leq 600$ \\
\hline UNIAXIAL COMPRESSIVE STRENGTH $(\mathbf{M P a})$ & \multicolumn{2}{l}{} \\
\hline 1 day & 28.7 & $\geq 14.0$ \\
\hline 3 days & 40.5 & $\geq 24.0$ \\
\hline 7 days & 44.8 & $\geq 34.0$ \\
\hline 28 days & 54.0 & - \\
\hline
\end{tabular}

\subsection{Experimental Procedures}

For this investigation, three different concrete mixes were produced. The first one was the reference concrete. The second concrete contained stabilized nano-silica, while the third concrete has a mix of stabilized nanosilica combined with silica fume. The concrete mixes were design to have a slump equal to $120 \pm 20 \mathrm{~mm}$ and a characteristic compressive strength $f_{c k}=45 \mathrm{MPa}$ at the age of 28 days. Multifunctional plasticizer, silica fume in suspension and polycarboxylate superplasticizer admixture containing nano-silica were considered in percentage with respect to cement content. The concrete mixes are shown in Table 2.

The material placing sequence during the concrete mixing was:

1) place the coarse aggregates in concrete mixer;

2) add half of the required water content;

3) mix until all coarse aggregates were wet;

4) add the cementitious materials (cement and silica fume);

5) mix for 30 seconds;

6) add the nano-silica dispersed in polycarboxylate based superplasticizer;

7) mix for another 30 seconds;

8) add the fine aggregate;

9) mix for more 30 seconds;

10) add slowly the remaining water until the desired slump was achieved;

11) mix for another 60 seconds. 
Table 2: Concrete mix design $\left(\right.$ per $\left.\mathrm{m}^{3}\right)$.

\begin{tabular}{l|l|l|l}
\hline & REFERENCE & $\begin{array}{l}\text { CONCRETE WITH } \\
\text { STABILIZED } \\
\text { NANO-SILICA }\end{array}$ & $\begin{array}{l}\text { CONCRETE WITH } \\
\text { STABILIZED } \\
\text { NANO-SILICA } \\
\text { AND SILICA FUME }\end{array}$ \\
\hline water/cement & 0.41 & 0.41 & 0.41 \\
\hline water/binders & 0.41 & 0.41 & 0.40 \\
\hline $\begin{array}{l}\text { Mix proportion } \\
\text { Cement : Sand : Coarse aggregate } 12.5 \mathrm{~mm}: \\
\text { Coarse aggregate } 19 \mathrm{~mm}\end{array}$ & $1: 1.26: 0.43: 1.72$ & $1: 1.93: 0.52: 2.07$ & $1: 1.84: 0.50: 2.01$ \\
\hline Cement $(\mathrm{kg})$ & 483 & 401 & 401 \\
\hline Sand $(\mathrm{kg})$ & 610 & 774 & 740 \\
\hline $\begin{array}{l}\text { Coarse aggregate } \\
12.5 \mathrm{~mm}(\mathrm{~kg})\end{array}$ & 208 & 207 & 202 \\
\hline $\begin{array}{l}\text { Coarse aggregate } \\
19 \mathrm{~mm}(\mathrm{~kg})\end{array}$ & & & 807 \\
\hline Water $(\mathrm{l})$ & 832 & 830 & 165 \\
\hline Multifunctional plasticizer $(\mathrm{kg})$ & 199 & 165 & $3.21(0.80 \%)$ \\
\hline Silica fume (suspension) $(\mathrm{kg})$ & $3.86(0.80 \%)$ & $3.21(0.80 \%)$ & $28.07(7.0 \%)$ \\
\hline $\begin{array}{l}\text { Polycarboxylate superplasticizer admixture } \\
\text { containing nano-silica }(\mathrm{kg})\end{array}$ & - & - & $2.09(0.52 \%)$ \\
\hline
\end{tabular}

In order to keep the water cement ratio constant, the amount of water present in the silica fume suspension was considered in the concrete mix design. Slump was determined according to the Brazilian NBR NM 67 Standard [37]. Concrete was cast into cylindrical molds $(10 \times 20 \mathrm{~cm})$ according to the Brazilian NBR 5738 specification [38]. A total of 15 cylindrical specimens were cast for each concrete mix. After 24 hours, the specimens were stripped from the molds and kept immersed in a tank with water until the day of testing. Before testing, the specimens had their top and bottom surfaces rectified. All these procedures were conducted at laboratory facilities of Wanmix Concrete Company, in Lagoa Santa, Brazil.

Concrete compressive strength tests were performed according to the Brazilian Standard NBR 5739 Standard [39]. For each mix design, five specimens were tested at the ages of 3, 7 and 28 days. Concrete secant modulus of elasticity determination was carried out in accordance to Brazilian NBR 8522 standard [40]. For each mix design, three specimens were tested at the ages of 3, 7 and 28 days. Linear variable displacement transducers were used for evaluation of the concrete strains. The concrete maximum stress corresponded to $40 \%$ of the respective compressive strength. A 2,000 kN servo-controlled digital electric hydraulic testing machine, manufactured by Mohr \& Feder Haff Losenhausen, was used in all these tests. All tests were performed at Holcim laboratory facilities in Pedro Leopoldo, Brazil.

A scanning electron microscope Quanta FIB EGF 3D FEI was employed in the microstructural evaluation of concretes. Backscattered (BSE) and secondary electrons (SE) detectors were used. These analyses were carried out at the Federal University of Minas Gerais Microscopy Center.

For microscopic analysis, samples of concrete slices were first immersed in acetone aiming to stop the cement hydration process. At the age of 2 months, the samples were then placed into a cylindrical mold with epoxy resin. Once they were impregnated, the resin was left to polymerize. After that, the samples were polished using $\mathrm{SiC}$ paper and isopropanol as lubricant, and then stored in a desiccator. Before the microscopic analyses, the samples were immersed in isopropyl alcohol for 5 minutes. The carbon coating process of samples was done using a LEICA EM SCD 500 equipment.

\section{RESULTS AND DISCUSSION}

During mixing, the concretes with stabilized nano-silica and with silica fume combined with nano-silica were easy to handle and showed good cohesion without mobility loss. The incorporation of nano-silica to the polycarboxylate chemical admixture is very efficient, since it allows the nano-silica to be well dispersed in the 
concrete mass during mixing. The reference concrete as well as the concretes with stabilized nano-silica satisfied the slump design requirements of $120 \pm 20 \mathrm{~mm}$

The results of concrete average compressive strength at each age are presented in Table 3 , with their respective standard deviations. These results can also be seen in Figure 1. In order to compare the concrete average compressive strength, Student's t-test with a significance level of $95 \%(\alpha=0.05)$ was employed. In this case, the two samples had 8 degrees of freedom; the corresponding value of $t$ (for $\alpha=0.05$ ) is equal to 2.306. Table 4 presents these results. In this table, codes R, nS and SF are used to denote reference, nanosilica and silica fume, respectively.

Table 3: Concrete average compressive strength and corresponded standard deviations.

\begin{tabular}{l|l|l|l}
\hline CONCRETE MEAN COMPRESSIVE STRENGTH AND CORRESPONDED STANDARD DEVIATION (MPa) \\
\hline CONCRETE & AGE = 3 DAYS & AGE = 7 DAYS & AGE = 28 DAYS \\
\hline Reference & $50.6 \pm 0.17$ & $57.7 \pm 1.21$ & $70.0 \pm 0.87$ \\
\hline Stabilized nano-silica & $64.4 \pm 1.62$ & $69.2 \pm 1.58$ & $76.6 \pm 1.42$ \\
\hline Stabilized nano-silica and silica fume & $64.6 \pm 1.21$ & $79.3 \pm 1.14$ & $86.5 \pm 1.74$ \\
\hline
\end{tabular}

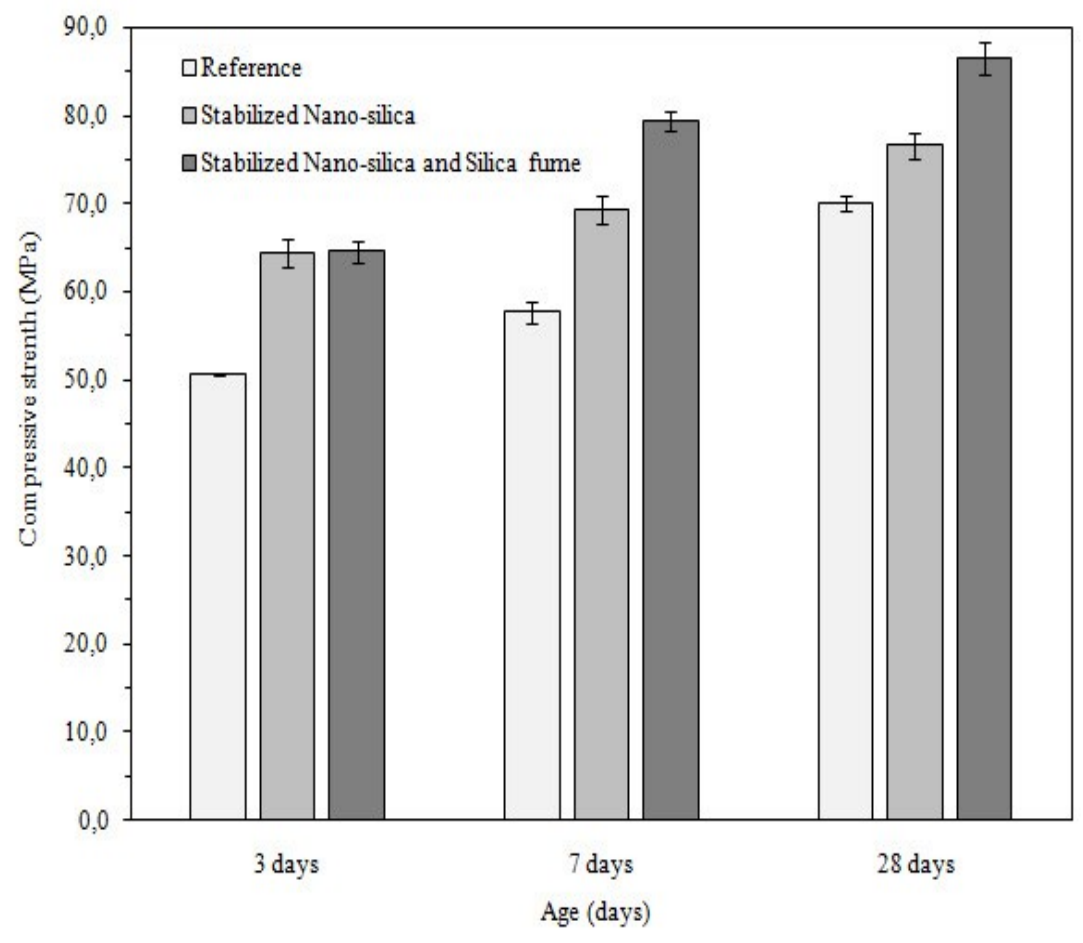

Figure 1: Concrete average compressive strength.

The analysis of these test results reveals first that the concrete compressive strength values satisfy the specified $f_{c k}$ of $45 \mathrm{MPa}$ at the age 28 days. In all ages, the calculated standard deviations were always less than $5 \%$ of the corresponded measured strength. These results also show that the compressive strength of concrete made only with stabilized nano-silica was always significantly higher in relation to the reference concrete: a gain of $27 \%$ was found at 3 days, $20 \%$ at 7 days and $11 \%$ at 28 days. In the case of concrete with addition of stabilized nano-silica and silica fume, the strength was even higher with respect to the reference concrete: a gain of $28 \%$ was obtained at 3 days, $37 \%$ at 7 days and $24 \%$ at 28 days.

The Student's t-test analysis of the average compressive strength of the different concrete also shows that the concrete with addition of stabilized nano-silica and silica fume had a significant gain in strength with respect to the concrete containing only stabilized nano-silica. This result indicates the synergistic effect when nano-silica and silica fume are combined. 
Table 4: Student's t-test analysis of the average compressive strength for the different concretes.

\begin{tabular}{l|l|l|l}
\hline $\begin{array}{l}\text { AGE } \\
\text { (DAYS) }\end{array}$ & $\begin{array}{l}\text { REFERENCE VERSUS } \\
\text { NANO-SILICA } \\
\mathbf{R} \times \mathbf{n S}\end{array}$ & $\begin{array}{l}\text { REFERENCEVERSUS } \\
\text { NANO-SILICA + SILICA FUME } \\
\mathbf{R} \times(\mathbf{n S}+\mathbf{S F})\end{array}$ & $\begin{array}{l}\text { NANO-SILICAVERSUS } \\
\text { NANO-SILICA + SILICA FUME } \\
\mathbf{n S} \mathbf{x} \text { (nS + SF) }\end{array}$ \\
\hline 3 & $\begin{array}{l}\mathrm{t}_{\text {Student }}=-18.537 \\
\mathrm{R}<\mathrm{nS}\end{array}$ & $\begin{array}{l}\mathrm{t}_{\text {Student }}=-33.123 \\
\mathrm{R}<\mathrm{nS}+\mathrm{SF}\end{array}$ & $\begin{array}{l}\mathrm{t}_{\text {Student }}=-0.198 \\
\mathrm{nS}=\mathrm{nS}+\mathrm{SF}\end{array}$ \\
\hline 7 & $\begin{array}{l}\mathrm{t}_{\text {Student }}=-12.800 \\
\mathrm{R}<\mathrm{nS}\end{array}$ & $\begin{array}{l}\mathrm{t}_{\text {Student }}=-26.440 \\
\mathrm{R}<\mathrm{nS}+\mathrm{SF}\end{array}$ & $\begin{array}{l}\mathrm{t}_{\text {Student }}=-10,709 \\
\mathrm{nS}<\mathrm{nS}+\mathrm{SF}\end{array}$ \\
\hline 28 & $\begin{array}{l}\mathrm{t}_{\text {Student }}=-8.976 \\
\mathrm{R}<\mathrm{nS}\end{array}$ & $\begin{array}{l}\mathrm{t}_{\text {Student }}=-16.984 \\
\mathrm{R}<\mathrm{nS}+\mathrm{SF}\end{array}$ & $\begin{array}{l}\mathrm{t}_{\text {Student }}=-8,571 \\
\mathrm{nS}<\mathrm{nS}+\mathrm{SF}\end{array}$ \\
\hline
\end{tabular}

The values of the secant modulus of elasticity of the different concretes at each tested age are presented in Table 5. These results are also shown in Figure 2. Student's t-test was also employed to compare the average secant modulus of elasticity of the different concretes. In this case, the two samples had 4 degrees of freedom: consequently the corresponding value of $t$ (for $\alpha=0.05$ ) is equal to 2.776. Table 6 presents these results, where the terms $\mathrm{R}, \mathrm{nS}$ and $\mathrm{SF}$ are used to denote reference, nano-silica and silica fume, respectively.

Table 5: Concrete average modulus of elasticity and corresponded standard deviations.

CONCRETE SECANT MODULUS OF ELASTICITY AND CORRESPONDED STANDARD DEVIATION (MPa)

\begin{tabular}{l|l|l|l}
\hline CONCRETE & AGE $=$ 3 DAYS & AGE = 7 DAYS & AGE = 28 DAYS \\
\hline Reference & $30682 \pm 1591$ & $33738 \pm 1802$ & $34812 \pm 2119$ \\
\hline Stabilized nano-silica & $38810 \pm 3241$ & $40802 \pm 355$ & $39834 \pm 803$ \\
\hline Stabilized nano-silica and silica fume & $36948 \pm 845$ & $39000 \pm 1935$ & $41368 \pm 1593$
\end{tabular}

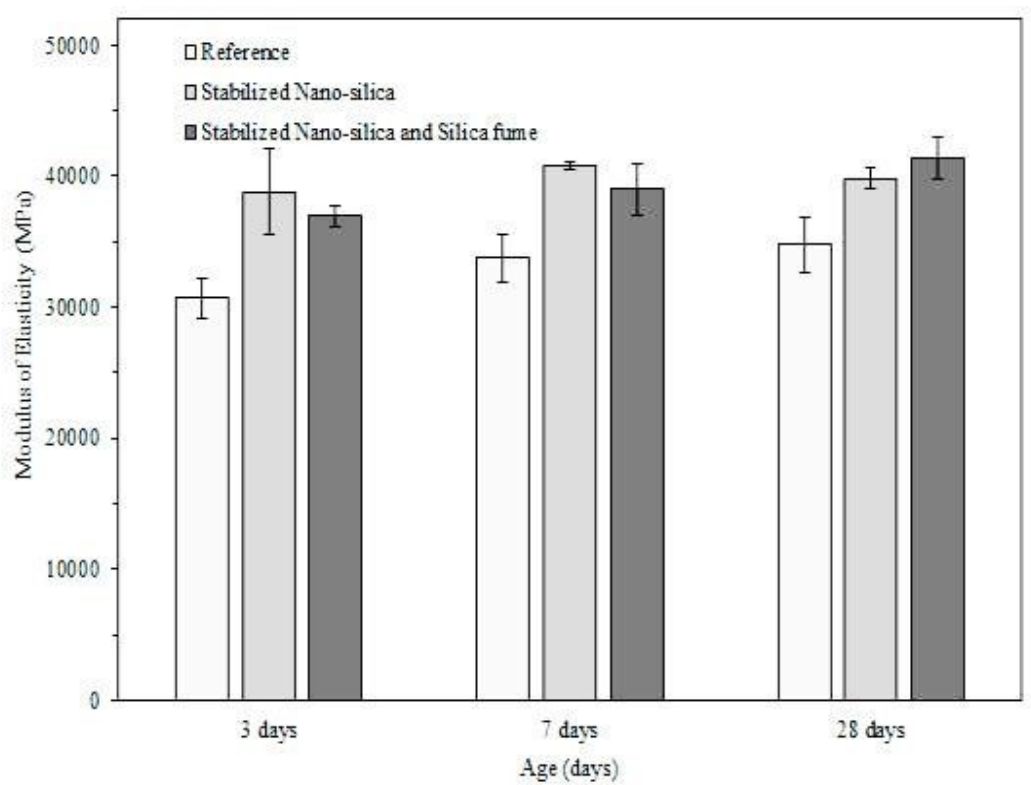

Figure 2: Secant modulus of elasticity of the different concretes. 
Table 6: Student's t-test analysis of the average secant modulus of elasticity for the different concretes

\begin{tabular}{|c|c|c|c|}
\hline $\begin{array}{l}\text { AGE } \\
\text { (DAYS) }\end{array}$ & $\begin{array}{l}\text { REFERENCE VERSUS } \\
\text { NANO-SILICA } \\
R \times n S\end{array}$ & $\begin{array}{l}\text { REFERENCEVERSUS } \\
\text { NANO-SILICA + SILICA FUME } \\
R \times(\mathrm{nS}+\mathrm{SF})\end{array}$ & $\begin{array}{l}\text { NANO-SILICAVERSUS } \\
\text { NANO-SILICA + SILICA FUME } \\
n S \times(n S+S F)\end{array}$ \\
\hline 3 & $\begin{array}{l}\mathrm{t}_{\text {Student }}=-3.890 \\
\mathrm{R}<\mathrm{nS}\end{array}$ & $\begin{array}{l}\mathrm{t}_{\text {Student }}=-6.024 \\
\mathrm{R}<\mathrm{nS}+\mathrm{SF}\end{array}$ & $\begin{array}{l}\mathrm{t}_{\text {Student }}=0.963 \\
\mathrm{nS}=\mathrm{nS}+\mathrm{SF}\end{array}$ \\
\hline 7 & $\begin{array}{l}\mathrm{t}_{\text {Student }}=-6.660 \\
\mathrm{R}<\mathrm{nS}\end{array}$ & $\begin{array}{l}\mathrm{t}_{\text {Student }}=-3.445 \\
\mathrm{R}<\mathrm{nS}+\mathrm{SF}\end{array}$ & $\begin{array}{l}\mathrm{t}_{\text {Student }}=1.588 \\
\mathrm{nS}=\mathrm{nS}+\mathrm{SF}\end{array}$ \\
\hline 28 & $\begin{array}{l}\mathrm{t}_{\text {Student }}=-3.838 \\
\mathrm{R}<\mathrm{nS}\end{array}$ & $\begin{array}{l}\mathrm{t}_{\text {Student }}=-4.283 \\
\mathrm{R}<\mathrm{nS}+\mathrm{SF}\end{array}$ & $\begin{array}{l}\mathrm{t}_{\text {Student }}=-1.490 \\
\mathrm{nS}=\mathrm{nS}+\mathrm{SF}\end{array}$ \\
\hline
\end{tabular}

The results show a significant increase in the secant modulus of elasticity for the concretes with stabilized nano-silica and this one combined the silica fume in relation to reference concrete for all investigated ages. The average values of the modulus of elasticity of concrete containing the combination of nano-silica with silica fume showed no significant difference in relation to concrete containing only the addition of nano-silica in ages studied. The results of improvement in the concrete mechanical properties corroborate the observations by Maghsoudi et al. [9] and by Sadrmomtazi et al. [15].

It is important to point out that with the addition of stabilized nano-silica and the combination of stabilized nano-silica and silica fume a reduction of $82 \mathrm{~kg}$ of cement per cubic meter of concrete was achieved with respect to the reference concrete. This corresponds to a $17 \%$ cement rate saving.

Figures 3 and 4 show the microstructure images with x250 magnification for two regions of the reference concrete. These regions with x500 magnifications are presented in figures 5 and 6 . The images were obtained by backscattered electrons.

In spite of the reference concrete be considered a high-performance concrete (with a water/cement ratio of 0.41 ), Figures 5 and 6 show evidence of the transition zone at the aggregate - cement paste interface (ITZ), usually considered the weakest region of the concrete. Letters A and $\mathrm{M}$ mean aggregate and cementitious matrix, respectively.

Figures 7 and 8 show microstructure images (x250 and x500 magnifications) for the concrete containing stabilized nano-silica, respectively. For this concrete, note the ITZ and cement matrix has improved with a much more dense structure. Figure 8 presents more clearly the differences between aggregate and cement matrix phases: practically there is no sign of the ITZ phase.

Figure 9 illustrates images for the reference concrete microstructure obtained by secondary electrons at x2000 magnification. Figure 10 shows a microstructure picture of the concrete with stabilized nano-silica with a much more dense structure. These results are in agreement with those obtained by Sadrmomtazi and Fasihi [18] and by Hemalatha et al. [23]. 


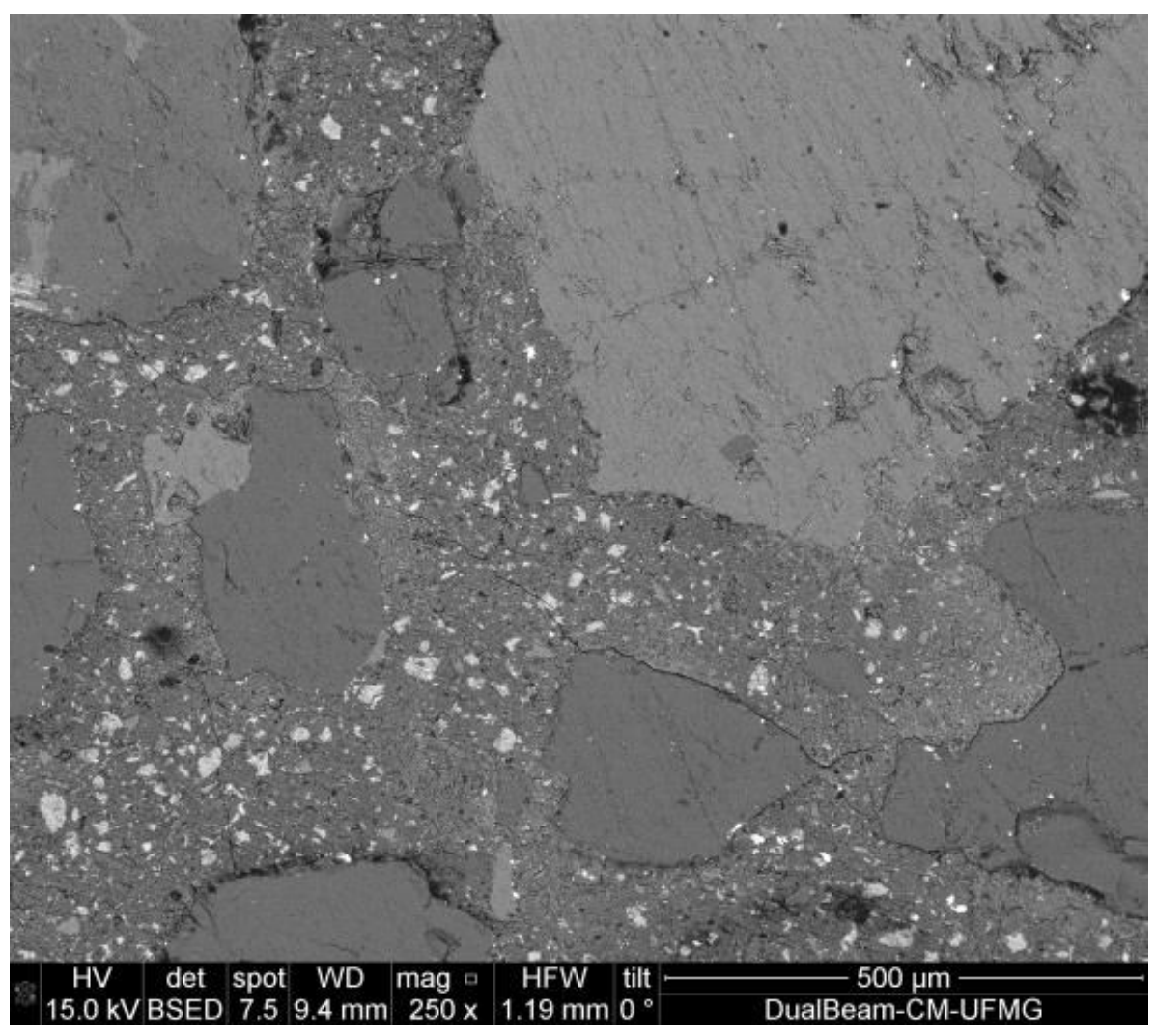

Figure 3: BSE micrograph of the reference concrete (x250 magnification) - area 1.

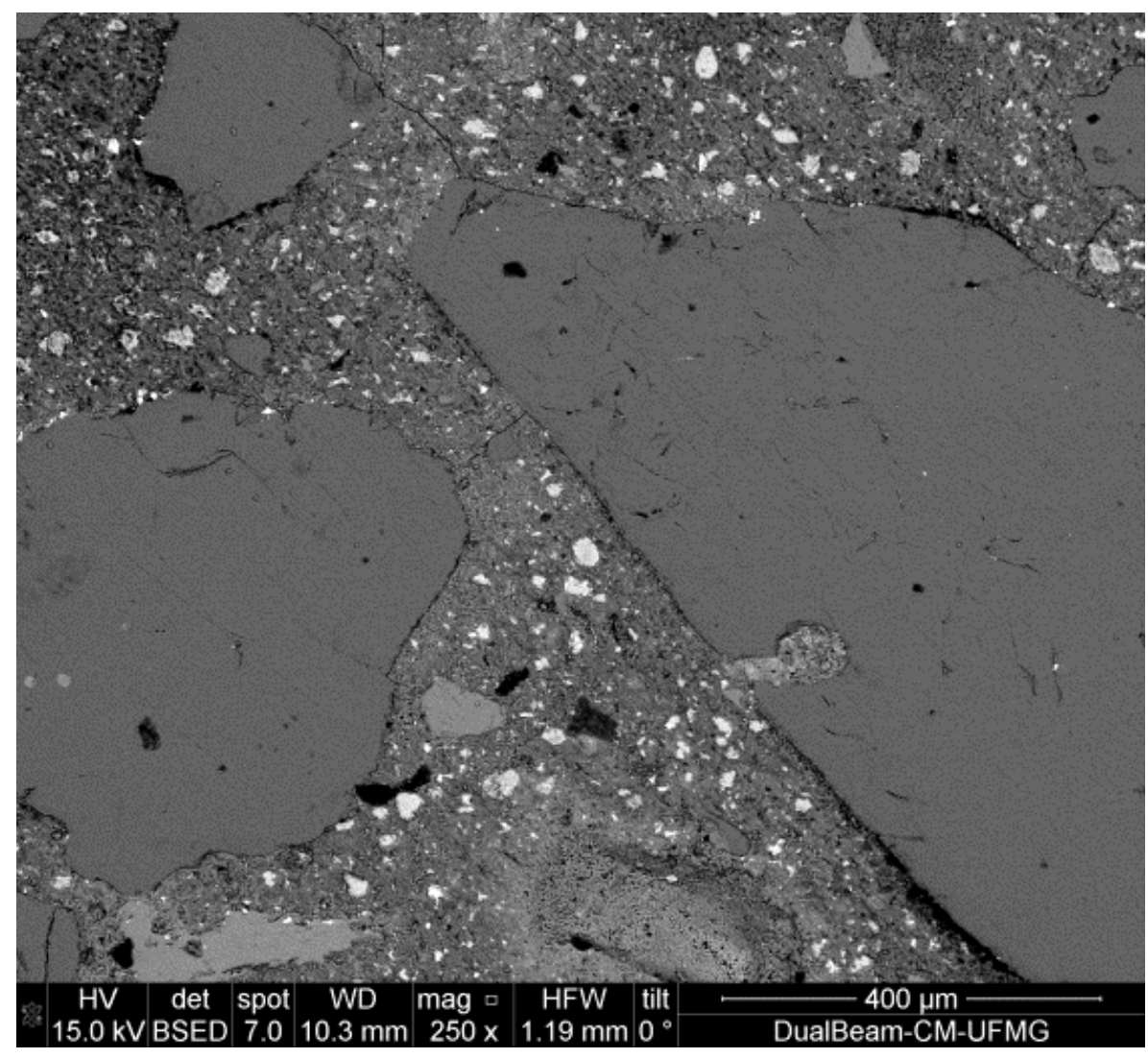

Figure 4: BSE micrograph of the reference concrete (x250 magnification) - area 2. 


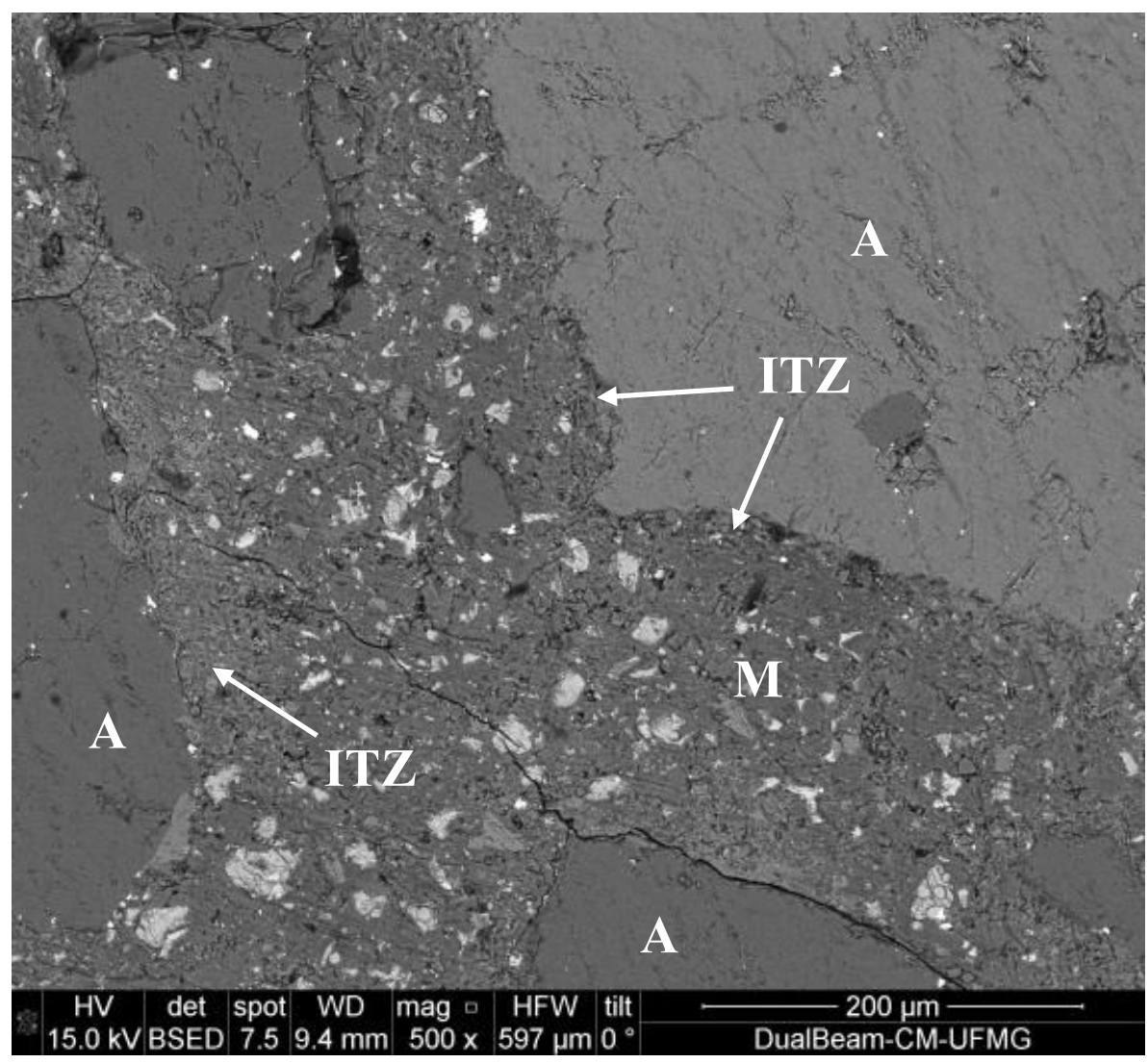

Figure 5: BSE micrograph of the reference concrete (x500 magnification) - area 1.

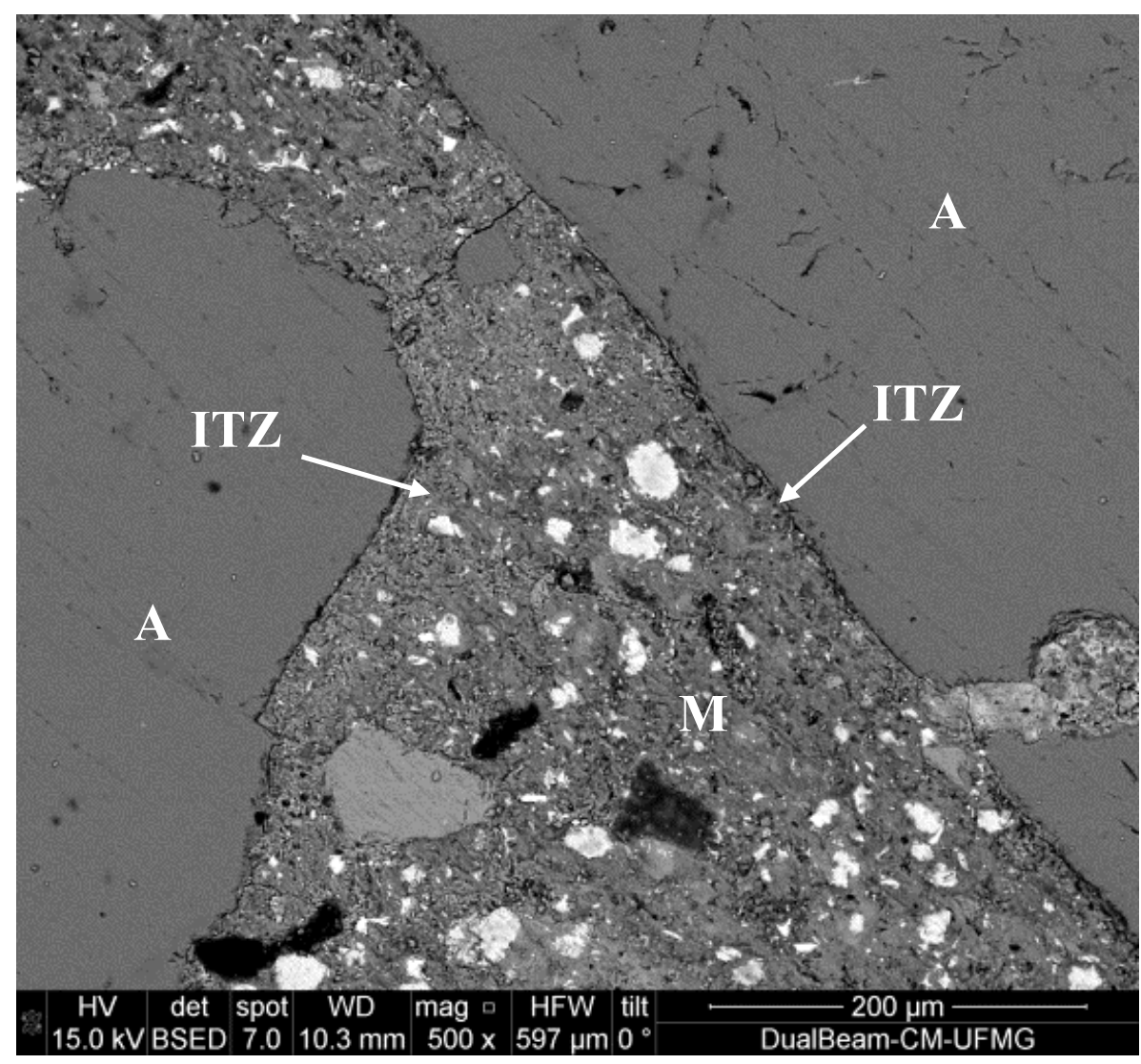

Figure 6: BSE micrograph of the reference concrete (x500 magnification) - area 2. 


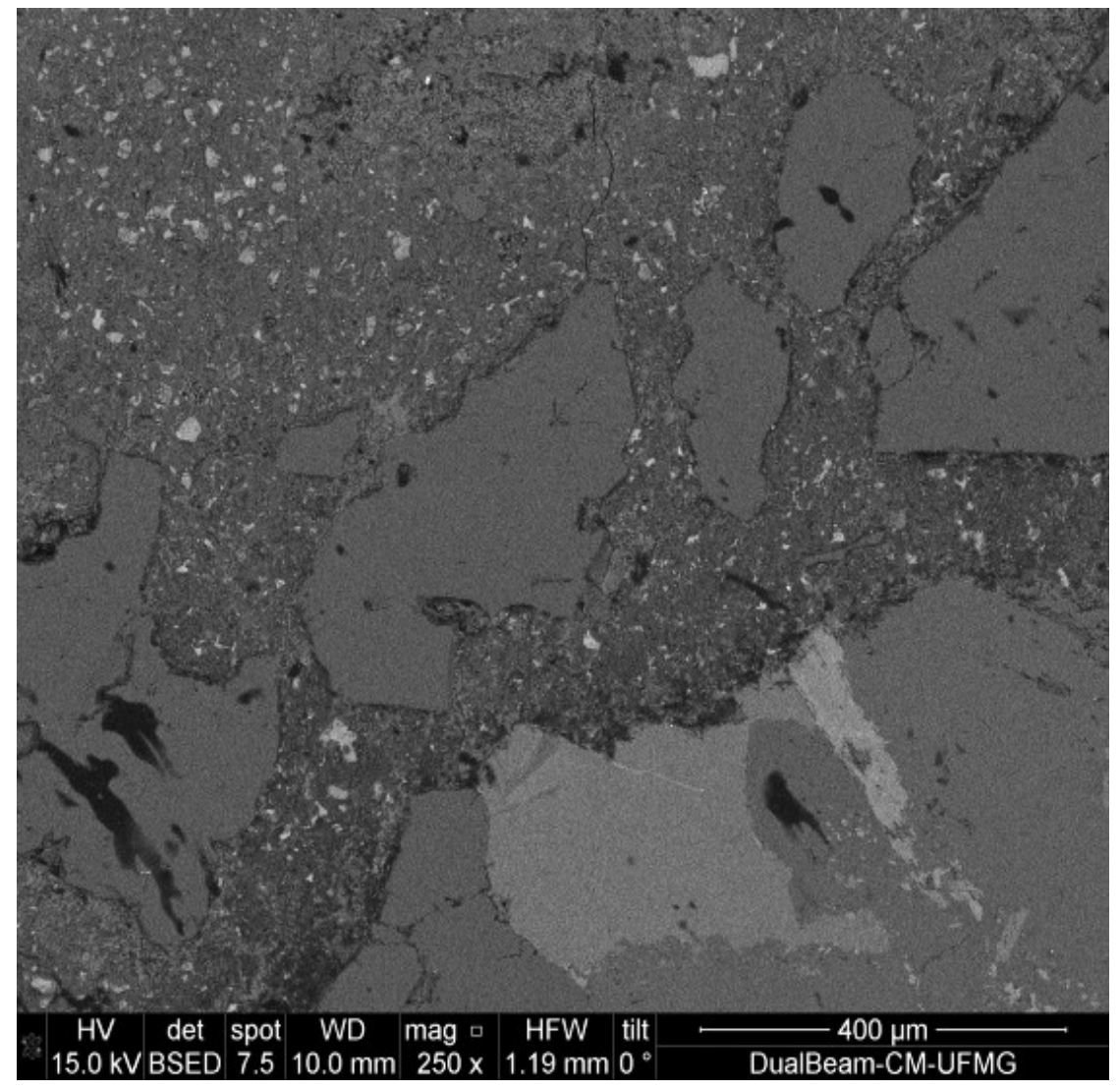

Figure 7: BSE micrograph of the concrete containing stabilized nano-silica (x250 magnification) - area 3.

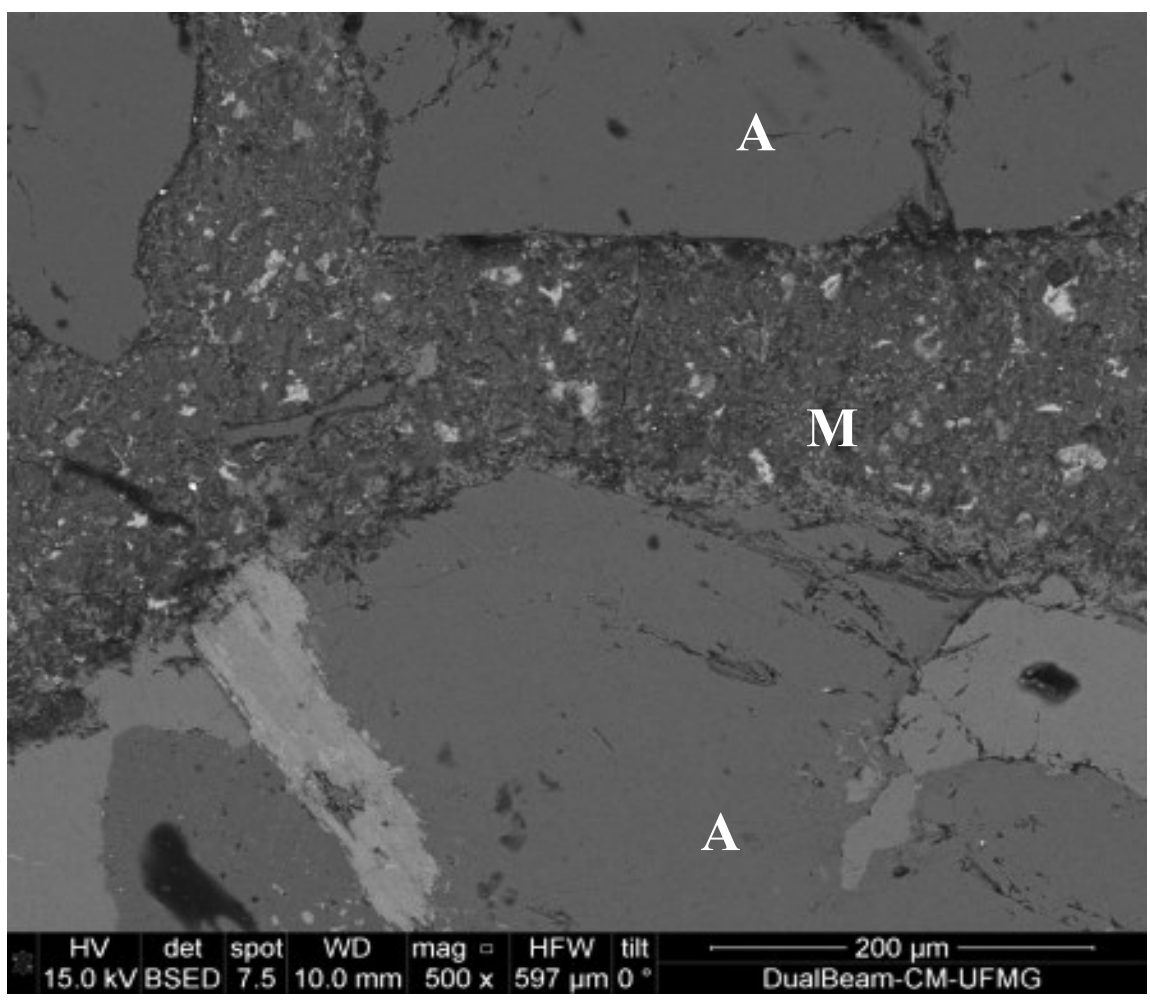

Figure 8: BSE micrograph of the concrete containing stabilized nano-silica (x500 magnification) - area 3. 


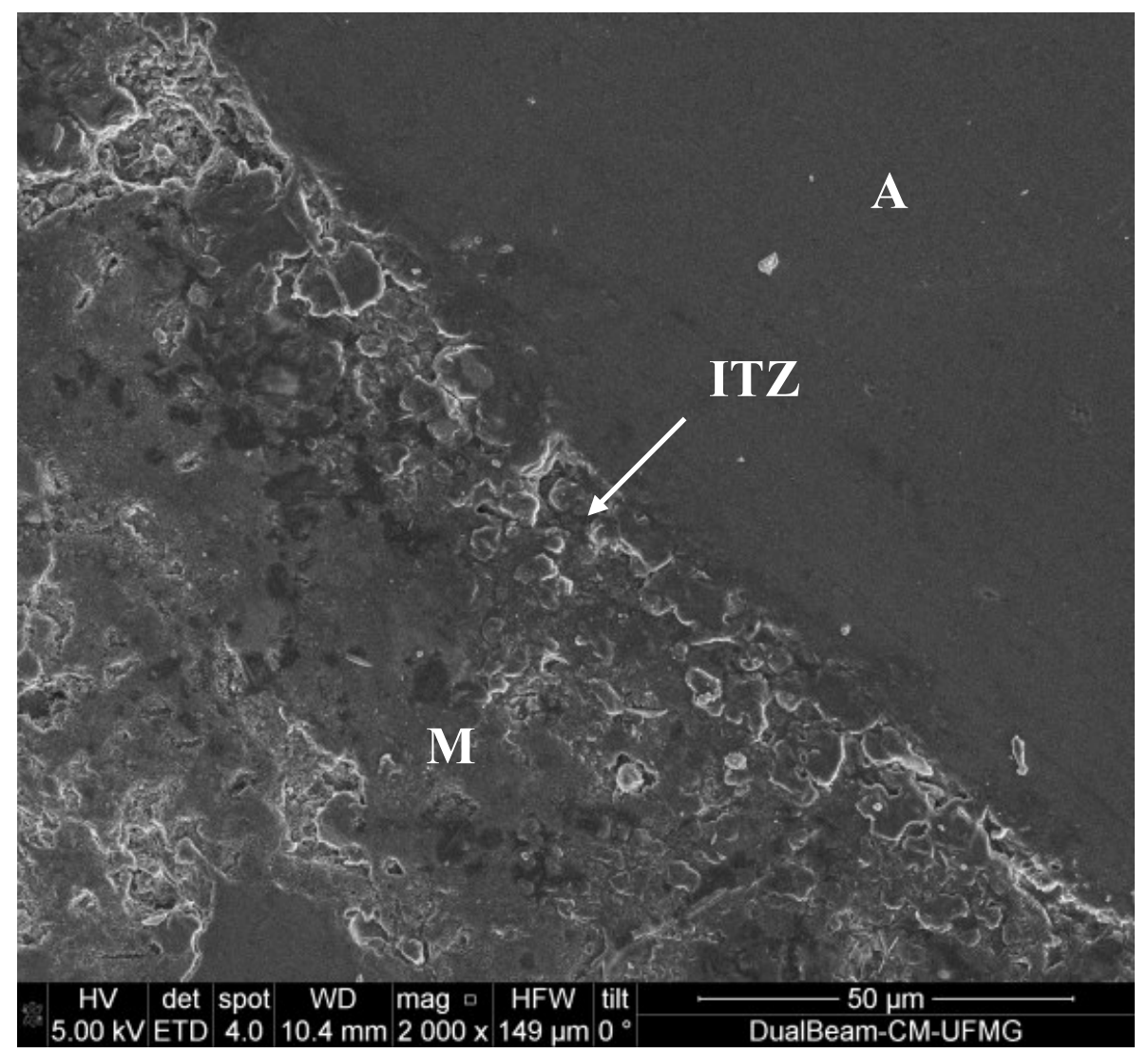

Figure 9: SE micrograph of the reference concrete (x2000 magnification).

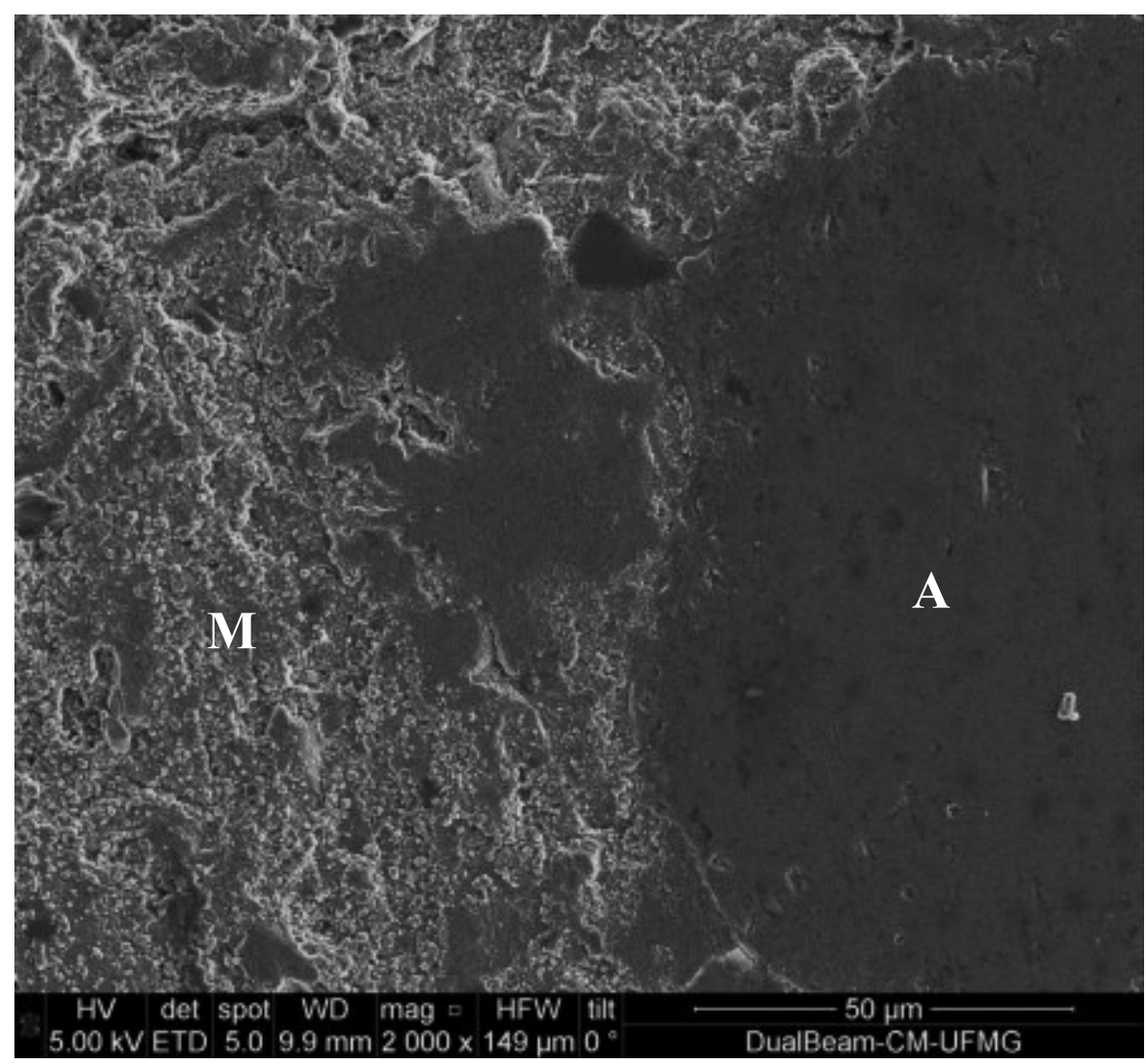

Figure 10: SE micrograph of the concrete containing stabilized nano-silica (x2000 magnification). 


\section{CONCLUSIONS}

The analysis of the test results indicates a substantial increase in the compressive strength and secant modulus of elasticity of concrete made with stabilized nano-silica. The incorporation of the nano-silica into the polycarboxylate based superplasticizer admixture contributes to a much better dispersion and homogenization of the material during the concrete mixing, which in turn made the concrete easy to handle.

The use of stabilized nano-silica proved to be very advantageous, especially when mixed with silica fume. When they were combined, a synergy effect occurred in the concrete that was of chemical nature in addition to the physical effect of better concrete particle packaging. The results also reveal that nano-silica is a good alternative to reduce cement consumption in the production of concretes with high mechanical strength.

The analysis by scanning electron microscopy showed improvements in the concrete microstructure with addition of stabilized nano-silica, which in turns contributes to high values in the mechanical properties.

\section{ACKNOWLEDGMENTS}

The authors acknowledge CAPES and FAPEMIG financial aid for the development of this research; Wanmix Concrete Company and Holcim Company for technical support during the experiments and Tecnosil/Silicon Company for providing the silica fume and stabilized nano-silica.

\section{BIBLIOGRAFHY}

[1] AITCIN, P.C., Concreto de Alto Desempenho, São Paulo, PINI, 2000.

[2] GLEIZE, P.J.P, "Nanotecnologia e materiais de construção" In: Isaia, G.C. (ed.), Materiais de construção civil e princípios de ciência e engenharia de materiais,v.2, cap. 50, pp. 1659-1685, São Paulo,Ibracon, 2007.

[3] GLEIZE, P.J.P. and PELISSE, R. F.,"Natureza da coesão do C-S-H e efeito de aditivos orgânicos na sua nanoestrutura", In: Anais do $49^{\circ}$ Congresso Brasileiro do Concreto, arquivo 49CBC0013.pdf, CD-ROM, Bento Gonçalves, Brasil, Ibracon, sept., 2007.

[4] CARDENAS, H.,KUPWADE, PATIL,K., EKLUND,S. "Corrosion mitigation in mature reinforced concrete using nano scale pozzolan deposition", In: Proceedings of the $2^{\text {nd }}$ International Conference on Sustainable Construction,v.1, pp. 29-40,Ancona, Italy, Milwaukee, UWM Center, jun., 2010.

[5] LI, G., "Properties of high-volume fly ash concrete incorporating nano-SiO${ }_{2}$ ", Cement and Concrete Research, v. 34, n.6, pp.1043-1049, 2004.

[6] LI, H., XIAO, H., OU, J.,“A study on mechanical and pressure-sensitive properties of cement mortar with nanophase materials”, Cement and Concrete Research, v.34,n. 3, pp. 435-438, 2004.

[7] LI, G., WANG, P.M., ZHAO, X., "Mechanical behavior and microstructure of cement composites incorporating surface-treated multi-walled carbon nanotubes”, Carbon, v. 43, n. 6, pp. 1239-1245, 2004.

[8] LI, G., WANG, P.M., ZHAO, X., "Pressure-sensitive properties and microstructure of carbon nanotube reinforced cement composites", Cement and Concrete Composites, v.29, n.5, pp. 377-382, 2007.

[9] MAGHSOUDI, A.A., MAGHSOUDI, M., NOORI, M., "Effect of nano particles on SCC", In: Proceedings of the $2^{\text {nd }}$ International Conference on Sustainable Construction Materials and Technologies (Special Technical Sessions), pp. 41-53, Ancona, Italy, Milwaukee, UWM Center, jun., 2010.

[10] GHASEMI, A.M., PARHIZKAR, T., RAMEZANIANPOUR, A., "Influence of coloidal $\mathrm{Nano}^{-\mathrm{SiO}_{2}}$ addition as silica fume replacement material on properties of concrete", In: Proceedings of the $2^{\text {nd }}$ International Conference on Sustainable Construction Materials and Technologies (Special Technical Sessions), pp. 23-29, Ancona, Italy, Milwaukee, UWM Center, jun., 2010.

[11] QUERCIA, G., HÜSKEN, G., BROUWERS, H.J.H., "Water demand of amorphous nano silica and its impact on the workability of cement paste", Cement and Concrete Research, v. 42,n. 2, pp. 344-357, 2012.

[12] SENFF, L., HOTZA, D., REPETTE, W.L., "Comportamento reológico de pastas de cimento com adição de sílica ativa, nanossílica e dispersante policarboxílico”, Revista Matéria, v. 15, n. 1, pp. 012-020, 2010.

[13] BOLLASSANI, M., SAMANI, M., "Effect of type, size, and dosage of nano-silica and microsilica on properties of cement paste and mortar", ACI Materials Journal, Technical Paper, v. 112, n. 2, March-April, pp.259-265, 2015.

[14] YAZDANBAKHSH, A., GRASLEY, Z., "The theoretical maximum achievable dispersion of nanoinclusions in cement paste", Cement and Concrete Research, v. 42, n.6, pp. 798-804, 2012. 
ABREU, G.B.; COSTA, S.M.M.; GUMIERI, A.G.; CALIXTO, J.M.F.; FRANÇA, F.C.; SILVA, C.; QUINÕNES, A.D. revista Matéria,

[15] SADRMOMTAZI, A., KHEIRKHAH, F., FASIHI, A., et al., "Properties of Rice Husk Ash Concrete Containing Nano-SiO ${ }_{2}$, In: Proceedings of the $2^{\text {nd }}$ International Conference on Sustainable Construction Materials and Technologies, v.1, pp. 201-208, Ancona, Italy, Milwaukee, UWM Center, jun., 2010.

[16] MADANI. H., BAGHERI, A., PARHIZKAR, T., "The pozzolanic reactivity of monodispersed nanosilica hydrosols and their influence on the hydration characteristics of Portland cement", Cement and Concrete Research, v. 42, n. 12, pp.1563-1570, 2012.

[17] CHOW, P.L., BARBHUIYA, S. "Hydration and microstructural properties of cement paste containing nano and microsilica" In: Sustainable Solutions in Structural Engineering and Construction, pp. 433-438, Chantawarangul, K., Suanpaga, W., Yazdani, S., Vimonsatit, V., Singh, A. (Editors), Fargo, USA, ISEC Press., 2014.

[18] SADRMOMTAZI, A., FASIHI, A., "Preliminary study on the mechanical behavior of mortar containing waste polypropylene fiber and nano- $\mathrm{SiO}_{2}$ ", In: Proceedings of the $2^{\text {nd }}$ International Conference on Sustainable Construction Materials and Technologies,v.1, pp. 209-216, Ancona, Italy, Milwaukee, UWM Center, jun., 2010.

[19] LOTHENBACH, B., SCRIVENER, K. and HOOTON, D.R., "Supplementary cementitious materials", Cement and Concrete Research, v. 41, n. 12, pp.1244-1256, 2011.

[20] TAYLOR, H.F.W., Cement Chemistry, 2nd ed., London, Thomas Telford, 1997.

[21] LEA, F.M., The chemistry of cement and concrete. $3^{\text {rd }}$ ed., London, Edward Arnold, 1970.

[22] MAlhotrA, V.M., MEHTA, P.K., Pozzolanic and cementitious materials, Advances in Concrete Technology, CANMET, Ottawa, Gordon and Breach Publishers, v.1, 1996.

[23] HEMALATHA, T., GUNAVADHI, M. , BHUVANESHWARI, B., et al., "Characterization of microand nano- modified cementitious system using micro analytical techniques", Cement and Concrete Research, v. 58, Apr., pp.114-128, 2015.

[24] MEHTA, P.K. "Sustainable cements and concrete for the climate change era - a review", In: Proceedings of the $2^{\text {nd }}$ International Conference on Sustainable Construction Materials and Technologies;v.1, pp. 1-10, Ancona, Italy, Milwaukee, UWM Center, jun., 2010.

[25] JO, B.W., KIM, C.H., TAE, G.H., et al., "Characteristics of cement mortar with nano-SiO $\mathrm{S}_{2}$ particles", Construction and Building Materials,v.21, n. 6, pp. 1351-1355, 2007.

[26] QING, Y., ZENAN, Z., DEYU, K., et al., "Influence of nano- $\mathrm{SiO}_{2}$ addition on properties of hardened cement paste as compared with silica fume", Construction and Building Materials, v. 21, n.3, pp. 539-545, 2007.

[27] LIN, D.F., LIN, K.L., CHANG, W.C., et al., "Improvements of nano-SiO ${ }_{2}$ on sludge/fly ash mortar" Waste Management, v. 28, n.6, pp. 1081-1087, 2008.

[28] SENFF, L., LABRINCHA, J.A., FERREIRA, V.M., et al., "Effect of nano-silica on rheology and fresh properties of cement pastes and mortars", Construction and Building Materials, v. 23, n.7, pp. 2487-2491, 2009.

[29] SENFF, L., HOTZA, D., REPETTE, W.L., et al., "Mortars with nano- $\mathrm{SiO}_{2}$ and micro- $\mathrm{SiO}_{2}$ investigated by experimental design", Construction and Building Materials, v.24, n.8, pp. 1432-1437, 2010.

[30] KONG, D., CORR, D.J., HOU, P., et al., "Influence of colloidal silica sol on fresh properties of cement paste as compared to nano-silica powder with agglomerates in micron-scale", Cement and Concrete Research, v. 63, Oct., pp.30-41, 2015.

[31] ASSOCIAÇÃO BRASILEIRA DE NORMAS TÉCNICAS.NBR 5733: High early strength Portland cement - specification, Rio de Janeiro, 1991.

[32] BOGUE, R.H., "Calculation of the compounds in Portland cement", Industrial and Engineering Chemistry, v. 1, n.4, pp. 192-197, 1929.

[33] BOGUE, R.H., The Chemistry of Portland Cement, 1st ed., New York, Reinhold Publishing Corporation, 1947.

[34] AMERICAN SOCIETY FORTESTINGMATERIALS. ASTM C150.Standard Specification for Portland Cement, West Conshohocken, PA, 2007.

[35] EUROPEAN COMMITTEE FOR STANDARDIZATION. EN.196-4, Methods of Testing Cement. Part 4 - Quantitative Determination for Constituent, European Standards, 2007. 
ABREU, G.B.; COSTA, S.M.M.; GUMIERI, A.G.; CALIXTO, J.M.F.; FRANÇA, F.C.; SILVA, C.; QUINÕNES, A.D. revista Matéria, v.22, n.2, 2017.

[36] ASSOCIAÇÃO BRASILEIRA DE NORMAS TÉCNICAS.NBR 15900-1.Mixingwater for concrete Part 1: Requirements, Rio de Janeiro, 2009.

[37] ASSOCIAÇÃO BRASILEIRA DE NORMAS TÉCNICAS.NBR NM 67.Concrete - Slump test for determination of the consistency, Rio de Janeiro, 1998.

[38] ASSOCIAÇÃO BRASILEIRA DE NORMAS TÉCNICAS.NBR 5738.Concrete - Procedure for casting and curing of concrete test specimens, Rio de Janeiro, 2003.

[39] ASSOCIAÇÃO BRASILEIRA DE NORMAS TÉCNICAS.NBR 5739. Concrete - compressive test of cylindrical specimens - test method, Rio de Janeiro, 1996.

[40] ASSOCIAÇÃO BRASILEIRA DE NORMAS TÉCNICAS.NBR 8522. Concrete - Determination of the elasticity modulus by compression, Rio de Janeiro, 2008. 